\title{
Vilified, Venerated, Forbidden: Jazz in the Stalinist Era
}

\section{MARTIN LÜCKE}

Translated from the German by Anita Ip.

Five years after jazz premiered in Western Europe, it also debuted in the Soviet Union and, within a short period, developed into a popular form of music. The Stalinist regime's attitude toward jazz, a musical style with strong connotations of freedom, moved from censorship and restrictions to state sponsorship. Domestic, foreign, economic, and ideological factors were responsible for this shift. However, throughout the entire Stalinist era, jazz remained an element of Soviet cultural life.

The Development and history of jazz in the USSR between 1920 and 1953 was in constant flux between prohibition, censorship and sponsorship. First and foremost, it was dependent on domestic, foreign, economic and ideological factors. Because of the political and social uproar after the OctoberRevolutions, jazz only arrived in the beginning of the 1920s, about five years later than the rest of Europe. This (jazz) was initiated by Valentin Parnach, who first came into contact with jazz at a concert of the American band Louis Mitchel Jazz Kings during his exile in Paris in 1921. He returned to Moskow a year later with a complete set of instruments. October 1, 1922 marks the birth of Soviet jazz, when Parnach and his band with the unwieldy name of Pervyj $v$ RSFSR èkscentričeskij orkestr - džaz-band Valentina Parnacha gave their first concert in Moskow. There are no extant recordings of the group, but critics described the music was as 'din' (Lärmmusik) in the style of the Italian futurists. ${ }^{1}$ Notwithstanding the negative reviews, a first cultural interest in jazz developed, especially because Parnach's initiative coincided with New Economic Politics (NEP), wherein private initiatives were permitted into Soviet economic policies. This was not without effect in the cultural sector.

Shortly thereafter, a brief boom in jazz was instigated by a few performances of American bands. Visually, the most engaging performance was the "Neger-Operette" Chocolate Kiddies (Šokoladnych rebjat) by Sam Wooding in 1925, which visited the Soviet Union after other engagements in Western Europe. Criticism focused on the visual aspects of the performance and the fact that all parties were black. "But it is not important how blacks play, how they dance, sing and think- that all is of no importance. What is important is that they are all black." ${ }^{2}$

The Benny Peyton Jazz Kings also had a performance, which was more successful because they played another kind of jazz. Wooding played a symphonic sweet-jazz, Peyton a rather improvised hot-jazz. This was a distinction that became significant to the politicization of jazz in the 1930s, when two kinds of jazzbourgois versus proletarian- were defined.

The founding of the Amadžaz under the direction of Aleksandr Cfasman marks the beginning of professional Soviet jazz. Amadžaz was founded by the Association of Authors of Moskow (Associacija

1 After a Parnach concert, a critic wrote that jazz had to be stopped before it was too late. "Džaz-band," in: Teatr $i$ muzyka, 5 (1923): 581.

2 V. Černojarov: “O džaz-bande, negrach i o tom, kak my došli do negrov,” in: Novyj sritel’, 12 (1926): 6-7.

Music \& Politics 1, Number 2 (Summer 2007), ISSN 1938-7687.

Article DOI: http://dx.doi.org/10.3998/mp.9460447.0001.201 


\section{Music and Politics Summer 2007}

moskovskich avtorov) in 1928, to promote popular music commercially. It was the first jazz band that was heard on the radio, that recorded the first jazz record and, in 1930, was the first to play in a motion picture.

Even the government attempted to professionalize jazz in society. The cultural ministry (Narodnyj kommissariat prosvešeniju; Narkompros) under Anatolij Lunačarskij organized a trip for the Leningrad-native Leopol'd Teplickij to the USA in order to study jazz. Teplickij returned in 1927 with a complete instrument collection, records and arrangements, and thereafter founded Pervyj konsertnyj džaz-band, whose members consisted entirely of classically trained professors of the Leningrad conservatory. ${ }^{3}$

\section{The Politicization of Jazz}

The massive political and economic upheavals in 1928/29, the abrupt end of the NÉP, the beginning of the first five-year plan, the cultural revolution and other factors negatively affected popular culture. At that point, the Soviet government increasingly tried to support proletarian elements in the arts, since popular culture had only opened itself to a small percentage of the populus.

From 1923 onward, several competing organizations were founded, who aimed to organize Soviet musical life. However, the Russian Union of Proletariat Musicians (Rossijskaja associacija proletarskich muzykantov) won the prominent position in 1928. ${ }^{4}$ The RAPM was explicitly against the light genre, exemplified an "anti-modern, anti-Western, anti-jazz and often also anti-classical" pose, and vehemently promoted the funding of proletarian music. ${ }^{5}$ The journal Proletarskij muzykant developed into propaganda against ill-favored composers and musicians. The aversion of the RAPM for "Antimelody, disharmony and atonality, against ,Meta-logic' [...] or the key words ,modernist and urbanist" on the one hand stood in line with the demand for a song of the masses for the proletariat to be "that musical style in which the ideology of the emerging communist communal society could be expressed most effectively." Even official Soviet departments admitted failures during this phase: it was not possible to establish an autonomous proletarian musical style in the first decade after the revolution. ${ }^{8}$

The deciding factor for the final politicization of jazz was Maksim Gor'kijs' essay O muzyke tolstych, which he wrote during his exile in Sorrento. In it, he equated jazz with homosexuality, drugs and eroticism. In the following paragraph, Gor'kij reports on his work in his villa.'

The dry knock of an idiotic hammer penetrates the utter stillness. One, two, three, ten, twenty strikes, and afterwards a wild whistling and squeaking as if a ball of mud was falling into clear water; then follows a rattling, howling and screaming like the clamor of a metal pig, the cry of a donkey or the amorous croaking of a monstrous frog. The offensive chaos of this insanity combines into a pulsing rhythm. Listen to this screaming for only a view

3 See Fejertag, Vladimir. Džaz ot Leningrada do Peterburga. St-Peterburg: Kul’tInformPress, 1999: 23.

4 Nelson, Amy. "The Struggle for Proletarian Music: RAPM and the Cultural Revolution," in Slavic Review 1 (2000): 101132.

5 Schwarz, Boris. Musik und Musikleben in der Sowjetunion 1917 bis zur Gegenwart. Wilhelmshaven: Heinrichshofen, $1982: 101$.

6 Gojowy, Detlef. "Musik in und seit der Stalinzeit," in Gabriel Gorzka (Hg.): Kultur im Stalinismus. Bremen: Edition Temmen, 1994: 117-130, here from p. 119.

7 Danuser, Hermann. Die Musik des 20. Fahrhunderts. Laaber: Laaber-Verlag, 1984: 198.

8 Korev, S. "Sovetskoe iskusstvo i ego potrebitel," in Sovetskoe iskusstvo 3 (1928): 36.

9 Gor'kij's essay is interesting from another viewpoint. Only a few year prior, in 1923, he was called a poputčyki, a sympathizer by Troztzki, because he had been abroad since 1919. Gor'kij's essay can thus also interpreted as an effort to ingratiate the Soviet Union in anticipation of a future return to the country. see Meyer, Krzystof. Schostakowitsch. Sein Leben, sein Werk, seine Zeit. Bergisch Gladbach: Lübbe, 1995: 86. 
minutes, and one involuntarily pictures an orchestra of sexually wound-up madmen, conducted by a Stallion-like creature who is swinging his giant genitals. ${ }^{10}$

Anatolij Lunačarskij agreed with Gor'kij, condemning the alleged connection between jazz, modern dance and sexuality, calling it "sonic idiocy in the bourgeois-capitalist world." 11

The RAPM enthusiastically adopted the viewpoints of both Gor'kij und Anatolij Lunačarskij for use in the introduction of their own proletarian music, a music for the working masses. ${ }^{12}$ The RAPM attacked syncopation, monotone rhythms or minor sixth and seventh chords. They claimed at the same time that Komsomol members would show less enthusiasm for social work under the influence of this light genre. Parallel to these actions, Komsomol members patrolled public dance clubs. The RAPM offered up lectures concerning so-called good music versus bad music. Foreign records were prohibited. ${ }^{13}$

It was one thing to find arguments against jazz; to find an adequate substitute for it was quite a different problem, for jazz had achieved popularity with the urban population in only a few short years. According to critics, the RAPM propaganda song (massovaja pesnja) remained colorless and dogmatic. Surely, one reason for this was that certain stylistic elements such as syncopations or diminished harmonies were excluded by that party. ${ }^{14}$ In 1930, however, the journal Raboči $i$ teatr published an article, which said that jazz could indeed become Soviet, if a suitable national repertoire were to be established. ${ }^{15}$ Thus a conflict between theory and practice, between ideology and public taste developed. The provisional solution to the problem was discovered in Germany, of all places. The first National-Socialist government in Thuringia passed a law in 1930, which equaled an indirect jazz-prohibition. ${ }^{16}$ Although the Stalinist worldview also rested on a friend-and-foe dichotomy, which is inherent to any dictatorship, an ideological problem emerged: German Nationalism could easily turn its back on the internationalism in jazz; however, for Communism, which saw itself as internationally understanding, this was an ideological paradox. Supporters of a "proletarian jazz" found arguments through Michael Gold. Gold, who headed the American division of the Russian Union of Proletarian Authors (Rossijskaja associa, cija proletarskich pisatelej RAPP) was of the opinion that jazz was a product of two suppressed classes: music of blacks ("Neger") and Jews. Therefore, jazz was music of the proletariat. ${ }^{17}$ Similar arguments appear with Edward Charles Smith, who claimed that "authentic" proletarian jazz stimulated the awareness of social classes. ${ }^{18}$ Soviet critics adopted and disseminated Gold's and Smith's arguments. ${ }^{19}$ According to this logic, two kinds of jazz existed: a bourgeois salon jazz and an "authentic" proletarian jazz. This, however, is a problematic distinction, since even "proletarian" jazz, due to its inclusion by the media in radio and record industry, had capitalist and commercial elements from the very beginning.

10 “O muzyke tolstych," in Pravda 4.18.1928.

11 Lunačarskij, Anatolij. "Social'nye istoki muzykal'nogo iskusstva," in Proletarskij muzykant 4 (1929): 12-20.

12 "The battle against the light genre has to be fought on all fronts. Another musical activity has to be established." Brjusova, N. "Dovesti do konca bor'bu s nepmanskoj muzykoj," in Za proletarskuju muzyku, 9 (1930): 1.

13 Vinogradov, V. “Opyt analiza lëgkogo žanra," in Proletarskij muzykant, 1 (1931): 17.

14 Rothstein,Robert A. “The Quiet Rehabilitation of the Brick Factory,” in Slavic Review 3 (1980): 373-388, here p. 374.

15 Razumovskij, A “Džaz na ėstrade, možet li džaz stat' sovetskim?," in Raboči i teatr 43 (1930): 7.

16 N.N. :"Wider die Negerkultur und für deutsches Volkstum," in Amtsblatt des Thüringischen Ministeriums für Volksbildung 6 (1930): 39-41. The decree prohibited „music with jazz band and percussion, Black dances, songs and other pieces [...] that are a slap in the face of German cultural aesthetics." The decree was valid for one year.

17 Gold, Michael. “Jews without Money.” New York: Liveright Publ., 1930.

18 N.N.: "Class Content of Jazz Musik," in: The Daily Worker. 10.21.1933.

19 N.N.: "Diskussija o džaze," in Sovetskaja muzyka 2 (1934): 67. 


\section{The Red Age of Jazz}

The year 1932 marked a turning point in the development of Soviet jazz. The successful fulfillment of the first Five-Year-Plan and the end of the cultural revolution, as well as the dissolving of the RAPM brought about a flowering of jazz that was accepted more openly than ever. ${ }^{20}$ This phase lasted until 1936 and is known as the Red Age of Jazz. ${ }^{21}$ In particular, the increased presence of mass media such as radio and records was responsible for this more enthusiastic reception. Beginning in 1932, the Leningrad radio station played jazz performances by Sergej Kolbas'ev. Between 1933 and 1934, the orchestra of Boris Krupyšev acted as the state orchestra at the same station. ${ }^{22}$

No American jazz band performed in the Soviet Union until 1956, since the Wooding Tour in 1926. However, several western and eastern-European groups did appear. The most well-known were the German Weintraub Syncopators, who were celebrated as victims of fascism in Leningrad and Moskow in 1935, and who toured the country for more than a year. ${ }^{23}$ Between 1934 and 1937, the Czech jazz band of Antonin Ziegler also performed several times in the Soviet Union and were even invited to the Kremlin.

\section{Jazz in Crisis}

A paradoxical picture marks the years until the Second World War. On the one hand, hundreds of musicians and audience members were arrested and assassinated during the Great Terror; on the other hand, jazz was supported through organizations and funding.

The Great Terror placed Soviet society into a period of great insecurity, and naturally did not hesitate to attack music associated with freedom and improvisation such as jazz. Not only jazz musicians disappeared into work camps, but also jazz fans who were rather unimportant from a political viewpoint, but quite important in terms of public reception. In 1935 Leopol'd Teplickij was sentenced to ten years in a worker's camp under the charge of sabotage and because of his Polish background; he was soon to be followed by Parnach in 1937, and in 1938 Georgij Landsberg, leader of the Leningrad radio jazz ensemble. $^{24}$

Similar fates befell hundreds of persons who were charged with conspiracy. ${ }^{25}$ But the mere contact with this liberal genre was not the primary reason for these arrests, for other jazz artists were spared from the cleansing. The common denominator of many of Soviet jazz musicians who fell victim to the repercussions were earlier travels and contacts overseas. ${ }^{26}$ Rather, the cleansings were part of a move to isolate the Soviet Union from the rest of the world from the inside out. As such, music became subject to ideological, cultural and political condemnation, because of the subsequent animosity against anything foreign. Musicians such as Leonid Utesov or Aleksandr Cfasman were spared any repressions, which is

\footnotetext{
20 According to the decision of the Central Command of April 23, 1923 all cultural organization were disbanded. The Soviet Composers Union became the governing body for music. The union published the journal Sovetskaja muzyka, in which the year-old position of the RAPM towards modern musical styles and elements were vehemently condemned. See Hakobian, Levon. Music of the Soviet Age. Stockholm: Kantat, 1998: 94.

21 See Stites, Richard. Russian Popular Culture. Cambridge: Cambridge University Press, 1992: 74.

22 Fejertag, Vladimir. Džaz ot Leningrada do Peterburga: 58.

23 N.N.: "Džaz Weintrauba" in Smena 6.28.1935. and "Masterstvo," in Večernaja Moskva 7.19.1935.

24 Fejertag, Vladimir. Džaz ot Leningrada do Peterburga: 56.

25 Starr, Frederick S. Red and Hot. Vienna: Hannibal-Verlag, 1990: 144.

26 Ibid., 147.
} 
explicable through their close contact with leading politicians. At the same time Utesov "converted" his style of jazz into a Soviet product "cleansed of decadence," which was now pedestaled. ${ }^{27}$

Simultaneously the newspapers Pravda and Izvestja were in a heated discussion about jazz, to which 19 partly polemical articles were dedicated. With the death of Maksim Gor'kij on June 18, 1936 his earlier denouncements of jazz became popular again. On November 21, 1936 a letter from two classical musicians to the Izvestja began a debate. In the letter, they protested that jazz was heard in Russian Sanatoriums, so much so that many classically trained musicians were deprived of the most basic means to earn a living. ${ }^{28}$ Three days later, Pravda published a response by Boris Šumjackij, who had been denounced in the first article in the debate as a "half-witted administrator." Šumjackij defended the existence of jazz on the grounds that it "brought joy to millions of people." ${ }^{29}$ Two letters followed this in Izvestija, both of which refuted Šumjackijs. ${ }^{30}$ However, the leader of the State Committee for Art, Platon Keržencev, emphasized in Pravda that there already existed two types of jazz. ${ }^{31}$ After still further articles debating the pros and cons of jazz, the debate reached a new stage, when the publishers of both newspapers became involved through an editorial.

With this a musical point of dispute became an issue around editorial politics and a monopoly of the opinions of party and government. At the same time, a change within cultural politics moved into the direction of folklorization, lyricism and musical entertainment. Pravda, which saw jazz as a litmus test for Soviet mass culture, accused the publishers of Izvestija of treachery and of anti-Soviet propaganda. It stated: "We also need jazz, and we will not allow bourgeois aesthetics and its proponents to dislodge it from the stage. [...] It is time that the publishers of Izvestja admitted that they cannot open their paper to the philistine blunderings about the situation of jazz." ${ }^{32}$

The newspaper debate ended with a plea for a proletarian jazz style, which was also reflected in the formation of various orchestras. The obvious goal was to advance and disseminate an ideologically correct jazz into society. In mid-1938 the governmental jazz orchestra (Gosdžaz) was unveiled. ${ }^{33}$ It was a type of political model orchestra, comparable to the Deutschen Tanz- und Unterhaltungsorchester (DTU), which was initiated by the National Socialist Party in 1941. Already in 1937 the magazine Sovetskaja muzyka had demanded a state orchestra that supported an ideologically correct, proletarian Soviet jazz. Even then, there was the realization that propagandistic mass-songs, supported by the RAPM, would not be able to shake the popularity of jazz. ${ }^{34}$

27 Stites, Richard. Russian Popular Culture. Cambridge: Cambridge University Press, 1992: 75.

28 N.N.: "Džaz ili simfonia?" in Izvestija. 11.21.1936. The authors refer to the Donbass-region, where jazz overwhelmed classical music in many areas of cultural life. The protest of the legitimate' musicians began when this trend appeared in the sanatoriums. A materialistic conflict stood behind the accusation: jazz musicians earned up to ten times as much as classically trained musicians who had to perform two or more tasks at a time.

29 N.N.: "Protiv chanžej i svjatoš," in Pravda, 11.24.1936.

30 "Ešče ras o džaze i simfoničeskoj muzyke," in Izvestija 12.1.1936. and see "Sumbur y tov. Šumjackogo," in Izvestija 12.1.1936.

31 N.N.: "O muzyke," in Pravda 12.4.1936.

32 N.N.: "Obyvatel'skaja boltovnja na stranicach »Izvestija«", in Pravda, 12.12.1936.

33 Gosudarstvennyj džaz-orkestr Sojus SSR. In its first years Gosdžaz was led by Matvej Blanter und Viktor Knuševickij. Initially, Aleksandr Cfasman was carved out for the conducting post because almost all musicians came from his band. He, however, was disqualified by his openly displayed Americanism. He called himself Bob and was married to an American. The orchestra was expanded from 14 to 34 musicians, and the instrumentation and its number made it similar to a symphony orchestra. See Jelagin, Juri. Kunst und Künstler im Sowjetstaat. Frankfurt: Fischer Bücherei, $1961: 166$.

34 Volkov-Lannit, Leonid. "Kakoj nam nužen džaz,” in Sovetskaja muzyka 5 (1937): 21-28; see p. 26. 
Gosdžaz had its premiere on November 6, 1938 at Bol’šoj-Theatre in Moskow. ${ }^{35}$ But the orchestra had little success, since the repertoire included hardly any jazz pieces. The following concert review is not atypical:

The annoyance of the crowd grew as preludes by Rachmaninov substituted the expected tango. Annoyance became an open scandal when Knushewitskijs "Tirana"-Arrangement sounded. It was drowned out by hisses, whistles, hooting and shouting. [...] This failure before the 'masses of the working-class population' evoked heated discussions. ${ }^{36}$

The orchestra did not become 'jazzier' until Leonid Utesov took over the orchestra in 1940.

Other Soviet republics such as Belarus or Azerbaijan followed suit after the model of Gosdžaz, and formed similar orchestras. Gosdžaz was proof to the hypothesis that jazz could indeed become Soviet, just as the debates in Pravda claimed in 1936. This would be the result if alleged Western, bourgeois and decadent influences and elements- improvisation, rhythm and instrumentation- were abandoned, while nationalist influences were advanced.

At the same time the Soviet railroad company planned to install Džaz-orkestr in 300 train stations, which were supposed entertain travelers. Stalin's first secretary Lazar Kaganovič and with the help of Leonid Utesov developed a brochure detailing how to assemble a jazz band. ${ }^{37}$ It is not clear how many groups were actually founded or what their quality was, however, the Russian jazz historian once exclaimed in an interview: "It was a parody, but they called it jazz."38

\section{Jazz during the Second World War}

Notwithstanding the horrors of the war, the great patriotic war was a positive phase for jazz. The distinction between bourgeois and proletarian was abandoned and music became a constant companion to the Red Army.

A cultural mobilization paralleled the military one: instrumentalists and whole orchestras volunteered, to serve in a koncertnaja frontovaja brigada. Jazz was only one form of cultural entertainment next to classical music, theatre and cabaret, but every squadron had its own swing band. "The number of jazz orchestras in the army was enormous. Many of the so-called musical brigades were made up of mainly jazz musicians. [...] These jazz ensembles could be commandeered anywhere, due to their small size. They were well-loved on the front." 40

The ensembles of the Red Army also played American jazz standards next to jazzed-up Russian folk songs, songs for the masses and ballads. Not only combat supplies came into the country through alliance between the Soviet Union and the United States, but also American culture. In addition, soldiers came in contact with US-jazz through radio broadcasts of the American forces, which were broadcast by shortwave

35 Only a few short years before, the RAPM had strictly denied opening the Bolshoi Theatre to the light genre. See Lebedinskij. "Novoe na muzykalnom fronte," in Proletarskij muzykant 6 (1929): 1-8; see p. 6.

36 Jelagin, Juri. Kunst und Künstler im Sowjetstaat. Frankfurt: Fischer-Bücherei, 1961: 170ff.

37 Kaganovič, Lazar and Leonid Utesov. Kak organisovat’ želesnodorožnye ansambli pesni $i$ oljaski $i$ džaz-orkestr. Moskow: without Publisher, 1939.

38 Interview mit Aleksej Batašev, Moskau, October 15, 2000.

39 Stites, Richard. "Frontline Entertainment," in Culture and Entertainment in Wartime Russia. Ed. Richard Stites. Bloomington: Indiana University Press, 1995: 126-140. See p.126ff.

40 Batašev, Aleksej. "Sovetskij džaz," in Moskva 1972: 92. - Sovetskoe iskusstvo published statistics that made extent of the cultural mobilization conceivable. "1.35 million artists, 473,000 concerts and performances, 3,685 brigrades." "Artisty na fronte," in Sovetskoe iskusstvo 9 May 1947. 
radio. At first the Soviet government had nothing against the steadily growing influence of jazz on the front and in the cities- in villages the situation was different. Some newspapers even published articles about American culture. ${ }^{41}$ But after the victory of the Red Army at Stalingrad, attacks on jazz experienced a resurgence. Leonid Utesov was accused of playing too many cheap imports and critics demanded more folk music at the front. ${ }^{42}$ Despite this, jazz bands performed everywhere for the celebration of the victory on May 9, 1945. Gosdžaz even played on the Red Square in Moskow.

\section{Renewed Repression}

Immediately after World War II, little was noticeable in terms of a renewed repression against jazz and other popular arts. Party and government allowed the people a brief respite. ${ }^{43}$ But at the end of 1946 nearly all prominent jazz musicians who enjoyed popularity during the war were arrested. It was no different for representatives of other popular art, as well as non-Russian musicians: "It was clearer than in the preceding attacks, that the concept of the enemy was highly undefined. Content and persons of the accusations were so widely defined that even former protégés came into the line of fire. At the center 'anticosmopolitanism' emerged in the form of anti-semitism: overwhelmingly, the victims were Jewish." ${ }^{44}$

There were musicians who were not arrested, however, they became the target for other repressions: Cfasman was stripped of his position as the leader of Jazz Broadcasting Orchestra (džaz-orkestr Vcecojusny radiokomitet), and Gosdžaz was re-named to the Entertainment-Orchestra of the RSFSR (Gosudarstvennyj estradnyj orkestr RSFSR) and asked to not play jazz anymore. In 1948 the last jazz bands of the Red Army were disbanded. The new repressions and limits were comparable to those from 1929/30: chords with diminished fifths, vibrato in the brass and the use of blue notes were prohibited; valved trumpets were considered an artistic perversion. ${ }^{45}$ Similar restrictions were valid for the use of trumpet mutes for making the wah-wah effect. "Excessive rhythm" was a charge that almost every jazz percussionist was found guilty of. Thereafter, Komsomol-Members and music students sympathetic to the party patrolled theatres, bars and cafes in order to supervise the compliance to these prohibitions. ${ }^{46}$

These repressions were not limited to jazz alone. Rather they extended to all popular art. Andrej Ždanov authored four resolutions for literature, theatre, film and music between 1946 and 1948. Each addressed the fight against the allegedly increasing influences from outside of the Soviet Union and against capitalism in the arts. ${ }^{47}$ Key terms such as "anti-method, dis-harmony and atonality" appeared in these resolutions, as well as the accusation that use of elements of Russian tradition and nationalistic elements were lacking. ${ }^{48}$ The RAPM had already spread these terms in the 1920s and 1930s. Russian critics now held the opinion that jazz was the music of the proletariat. Victor Gorodinskij, music critic of the

41 Compare "Muzyka v SŠA," in Literatura i iskusstvo 22 Aug. 1941. - "Muzyka v Soediennych štatach," in Sovetskoe iskusstvo 18 Sept. 1941.

42 Compare "Smotr sovetskoj èstrady," in Literatura i iskusstvo 19 Aug. 1944.

43 Hildermeier, Manfred. Geschichte der Sowjetunion. Munich: Oldenbourg, 1998: 716.

44 Ibid., p.720.

45 Blue notes are third and seventh scale degrees, which in jazz were lowered and not played on pitch.

46 Utesov, Leonid. "Spasibo serdce!," in Moskva 1976: 351.

47 See Hakobian, Levon. Music of the Soviet Age. Stockholm: Kantat, 1998: 198-215. - In regards to the resolutions see "Über die Zeitschriften ,Sveda' und ,Leningrad'. Aus dem Beschluß des ZK der KPdSU (B) vom 14. August 1946," as well as "Über den Film ,Das große Leben“. Aus dem Beschluß des ZK der KPdSU (B) vom 4. September 1946," in Beschlüsse des Zentralkomitees der KPdSU (B) zu Fragen der Literatur und Kunst (1946-1948). Moskau 1951: 3-10 and 25-31. - Beiträge zum sozialistischen Realismus. Grundsätzliches über Kunst und Literatur. Berlin 1953: 20-42. - "Ob opere ,Velikaja družba“ V. Muradeli," in Sovetskoe iskusstvo 14 Feb. 1948.

48 Ždanov, Andrey Alexandrovič. Über Kunst und Wissenschaft. Stuttgart: Verlag “Das neue Wort”, 1952: $46 \mathrm{ff}$. 
Komsomolskaja Pravda, claimed that only the ruling class in the USA, the bourgeoisie, could claim jazz for itself- not the general populous. In order to support his theses he pointed to Gor'kij's article from Pravda. ${ }^{49}$ Gorodinskij postulated in the same essay that the hitherto held division between sweet-jazz and hot-jazz could not be held up.

The bastardizations of jazz, all these 'sweet', 'hot', 'swing', 'Boogie-Woogie', 'Bebop' etc.these are merely different standards in an in no way different style, as the theoreticians of jazz assume without proof. One cannot speak of styles in jazz at all, because it lacks creative and artistic breadth. ${ }^{50}$

In the 1930s, Gorodinskij also defended his second thesis with the view that jazz should be seen as the product of proletarian art. Thus, all validation of jazz in all areas was undermined.

In the ensuing years, these major repressions pushed popular music to the outer borders of the Soviet Union. In regions such as the Baltics stations such as Voice of America or BBC, who broadcasted a wide selections of jazz, could be received..$^{51}$ In Estonia, an autonomous and lively jazz scene developed despite hard censorship. ${ }^{52}$ A report of the Central Committee from 1949 said:

Orchestras of four to eight people play often in night clubs, movie theaters and so forth. [This orchestra] imitated the performance style of American jazz musicians. They took over the dry rhythm, the abrupt harmony, which is robbed of any melody. ${ }^{53}$

Jazz did not exclusively survive the late stages of Stalinism on Soviet borders. In Moskow an initially limited youth-subculture (stiliagi) emerged around the popular genre, which recruited from the children of the new Russian elite. Especially in appearance, the stiliagi tried to distance themselves from the Komsomol. Close parallels to the German youth culture around swing are apparent. ${ }^{54}$ In 1953 the stiliagi were still a small group, but it became a widespread movement in the culture of Soviet youths. ${ }^{55}$

\section{Conclusion}

Between 1946 to Stalin's death, attempts were made to ban music and the mere mention of the word 'jazz.' This did succeed on the surface, but, through the burgeoning black market as well as in the Baltic republics, it was nevertheless possible to buy, hear and experience live performances in the USSR. ${ }^{56}$

The development of jazz between 1922 and 1953 moves between prohibition and limitation on the one hand, and government support on the other. These turbulent periods are most accurately described as a kind of wave, which consisted of domestic and international politics, economic issues and ideological factors and events. Phases of internal revolutions such as the first Five-Year-Plan (1928/29) were

49 See Gorodinski, Viktor. Geistige Armut in der Musik. Halle: Mitteldeutscher Verlag, 1952: 80f.

50 Ibid., p. 77.

51 Bljum, Arlen V. Sovetskaja zensura v epochu totalnogo terrora. Sankt-Peterburg: Akademiceskij Proekt, 2000 : 189.

52 Ojakäär, Walter. "Jazz in Estland," in Fazz in Europa. Darmstädter Beiträge zur Fazzforschung 3. Ed. Wolfram Knauer. Hofheim: Wolke, 1994: 95-106.

53 Quote after Edele, Mark. "Strange Young Men in Stalin's Moscow: The Birth and Life of the Stiliagi, 1945-1953," in Fahrbücher für Geschichte Osteuropas 1 (2002): 37-61. See 53.

54 For more information on the swing youth see Kurz, Jan. Swinging Democracy. Münster: Lit-Verlag, 1995.

55 Compare Edele, Mark. "Strange Young Men in Stalin's Moscow: The Birth and Life of the Stiliagi, 1945-1953," in Jahrbücher für Geschichte Osteuropas 1 (2002).

56 For more on the development of jazz in the Soviet Union after the death of Stalin see among others, Starr, Frederick S. Red and Hot. Vienna: Hannibal-Verlag, 1990: 144., S. 215-276. - Fejertag, Vladimir. Džaz ot Leningrada do Peterburga. StPeterburg: Kul'tInformPress, 1999: 23. 
accompanied by far-reaching regulations. The phases of internal 'rest' are a moderate advancement of jazz culture, affecting a growing influence on society.

Similarly, international affairs were not without effect on jazz. World War II was a positive period for jazz, because music was used in the Red Army in order to entertain on all fronts. The alliance with the USA also boosted jazz. For the first time since the 1920s, original American arrangements came to the Soviet Union. However, this was only a fleeting moment. From 1946 onward, the battle against alleged "cosmopolitan influences" in the arts once again made jazz a target. 